\title{
Streptozotocin-induced diabetes mellitus affects lysosomal enzymes in rat liver
}

\author{
G.B. Peres ${ }^{1}$, M.A. Juliano ${ }^{2}$, J.A.K. Aguiar ${ }^{1}$ and Y.M. Michelacci ${ }^{1}$ \\ ${ }^{1}$ Departamento de Bioquímica, Escola Paulista de Medicina, Universidade Federal de São Paulo, São Paulo, SP, Brasil \\ ${ }^{2}$ Departamento de Biofísica, Escola Paulista de Medicina, Universidade Federal de São Paulo, São Paulo, SP, Brasil
}

\begin{abstract}
It has been previously shown that dextran sulfate administered to diabetic rats accumulates in the liver and kidney, and this could be due to a malfunction of the lysosomal digestive pathway. The aim of the present study was to evaluate the expression and activities of lysosomal enzymes that act upon proteins and sulfated polysaccharides in the livers of diabetic rats. Diabetes mellitus was induced by streptozotocin in 26 male Wistar rats (12 weeks old), while 26 age-matched controls received only vehicle. The livers were removed on either the $10^{\text {th }}$ or the $30^{\text {th }}$ day of the disease, weighed, and used to evaluate the activity, expression, and localization of lysosomal enzymes. A $50-60 \%$ decrease in the specific activities of cysteine proteases, especially cathepsin B, was observed in streptozotocin-induced diabetes mellitus. Expression (mRNA) of cathepsins B and L was also decreased on the $10^{\text {th }}$, but not on the $30^{\text {th }}$ day. Sulfatase decreased $30 \%$ on the $30^{\text {th }}$ day, while glycosidases did not vary (or presented a transitory and slight decrease). There were no apparent changes in liver morphology, and immunohistochemistry revealed the presence of cathepsin B in hepatocyte granules. The decrease in sulfatase could be responsible for the dextran sulfate build-up in the diabetic liver, since the action of sulfatase precedes glycosidases in the digestive pathway of sulfated polysaccharides. Our findings suggest that the decreased activities of cathepsins resulted from decreased expression of their genes, and not from general lysosomal failure, because the levels of glycosidases were normal in the diabetic liver.
\end{abstract}

Key words: Liver; Diabetes mellitus; Lysosomal enzymes; Cathepsin; Glycosidase; Sulfatase

\section{Introduction}

Streptozotocin-induced diabetes mellitus (STZ-DM) in rats leads to a marked decrease in the urinary excretion of glycosaminoglycans (1). Decreased urinary excretion of exogenous dextran sulfate also occurs in STZ-DM, with accumulation of dextran sulfate in liver and kidney (2). Because dextran sulfate is very soluble in water, its presence in liver and kidney $48 \mathrm{~h}$ after administration suggests intracellular localization of these molecules.

The concentration of glycosaminoglycan also increased in diabetic kidney $(2,3)$, and there is evidence that both anabolic and catabolic pathways are involved (4,5). Decreased expression of lysosomal enzymes in diabetic kidney was recently reported (5), and autophagy was recently proposed as a therapeutic target for diabetic nephropathy (6).

Lysosomal enzymes are the main agents of the digestive process that takes place in autophagic vacuoles (reviewed in Ref. 7). Even though much of the pioneering research on autophagy comes from 40 years of studies on liver and isolated hepatocytes (8), and although lysosomes were discovered back in the 1950s by Christian de Duve (9), who also maintained a lifetime interest in the actions of insulin and glucagon on the liver (10), there are few studies on the expression and activities of lysosomal enzymes in the diabetic liver.

Most of the recent work on liver autophagy has focused on lipid digestion (lipophagy) $(11,12)$ and glycogen digestion (13). There are few studies of liver lysosomal enzymes that act upon proteins and sulfated polysaccharides. The aim of the present study was to investigate the expression and activities of lysosomal hydrolases in the liver of rats with STZ-DM, in order to elucidate the mechanisms responsible for the dextran sulfate build-up. Two different stages of the disease were studied: 10 days (initial diabetic state) and 30 days (diabetic nephropathy).

Correspondence: Y.M. Michelacci, Disciplina de Biologia Molecular, Departamento de Bioquímica, Escola Paulista de Medicina, UNIFESP, Rua Três de Maio, 100, 04044-020 São Paulo, SP, Brasil. Fax: +55-11-5573-6407. E-mail: yara.bioq@epm.br

Present address of J.A.K. Aguiar: Departamento de Bioquímica, Universidade Federal de Juiz de Fora, Juiz de Fora, MG, Brasil.

Received July 23, 2013. Accepted March 6, 2014. First published online May 9, 2014. 


\section{Material and Methods}

\section{Animals, urine, and tissue}

The Ethics Committee of Escola Paulista de Medicina, UNIFESP approved the present research (CEP No. 0170/ 09), which was carried out in accordance with UNIFESP guidelines, and also in accordance with EC Directive 2010/63/EU for animal experiments.

Male Wistar rats $(n=52), 12$ weeks of age $(275-360 \mathrm{~g}$ body weight), were randomly assigned to one of four groups: control day 10, diabetes (DM) day 10, control day 30 , and diabetes day 30 . Before the induction of DM, the animals were weighed, blood glucose was measured (Advantage Kit Roche, Switzerland), and the animals were placed in metabolic cages for 24-h urine collection. Diabetes was induced in the 26 rats of DM groups by a single intraperitoneal injection of $60 \mathrm{mg} / \mathrm{kg}$ body weight STZ. The drug was dissolved in $300 \mu \mathrm{L} 10 \mathrm{mM}$ sodium citrate buffer, $\mathrm{pH}$ 4.5. These animals were fed standard laboratory chow and a $5 \%$ glucose solution ad libitum for $72 \mathrm{~h}$. Afterward, the glucose solution was replaced by water. Glycemia was measured $72 \mathrm{~h}$ after STZ administration, and also at the end of each experiment (either $10^{\text {th }}$ or $30^{\text {th }}$ day). Only animals that, at $72 \mathrm{~h}$, presented blood glucose higher than $250 \mathrm{mg} / \mathrm{dL}$ were considered "diabetic" (14). The 26 age-matched animals that served as controls received only $300 \mu \mathrm{L}$ buffer and were fed standard laboratory chow and water ad libitum.

At the end of each experiment, body weight was again measured, and the rats were placed in metabolic cages for 24-h urine collection. The 24-h urine volume was measured and the urine was centrifuged at $1000 \mathrm{~g}$ for $10 \mathrm{~min}$ at room temperature to remove debris and used for determination of creatinine, total protein, and albumin. Creatinine was quantified by the picric acid reaction under alkaline conditions (CELM creatinine kit, Brazil), total protein was measured by the pyrogallol red-molybdate complex method (Sensiprot, Labtest, Brazil) (15), and albumin was determined by two methods: radial immunodiffusion based on precipitation with rabbit antibodies against rat albumin (1), and ELISA using a Bethyl E110-125 Rat Albumin Quantification Set (USA). The results obtained for total protein and creatinine were published in Peres et al. (5). After the urine was collected, the rats were killed, and the livers were removed, weighed, and carefully cut into small fragments ( $\sim 100 \mathrm{mg}$ each). These fragments were used for RNA extraction, measurement of enzyme activities, Western blotting, and quantification of total protein. The liver fragments were put into sterile tubes, frozen in liquid nitrogen, and stored at $-70^{\circ} \mathrm{C}$ until use.

\section{Liver enzyme activities}

To measure the enzyme activities, liver samples ( $\sim 100 \mathrm{mg}$ ) were disrupted in liquid nitrogen and resuspended in $1 \mathrm{~mL} 50 \mathrm{mM}$ Tris-HCl buffer, $\mathrm{pH} 7.4$, containing $200 \mathrm{mM} \mathrm{NaCl}$ and $250 \mathrm{mM}$ sucrose (16) plus $1 \mathrm{~mL}$
$0.2 \%$ Triton $X-100$. After standing for $10 \mathrm{~min}$ in an ice bath, debris was removed by centrifugation $(12,000 \mathrm{~g}$, $\left.10 \mathrm{~min}, 4^{\circ} \mathrm{C}\right)$, and aliquots of the supernatant $(100 \mu \mathrm{L})$ were stored in sterile tubes at $-70^{\circ} \mathrm{C}$ until use (tissue extracts).

Protease activities were quantified by fluorometric assays using either carbobenzoxy-Phe-Arg-7-amide-4methylcoumarin (Z-FR-MCA; Sigma-Aldrich, USA) or $\varepsilon-$ $\mathrm{NH}_{2}$-caproyl-Cys(Bzl)-Cys(Bzl)-MCA (synthesized by Prof. Dr. Maria A. Juliano) (17) as substrates. These substrates were used to quantify total cysteine proteases and cathepsin B, respectively. Incubation was carried out in dark microplates (Corning, USA), in $50 \mathrm{mM}$ phosphate buffer, $\mathrm{pH}$ 6.3, containing $10 \mathrm{mM}$ EDTA. The enzymes (50 $\mu \mathrm{g}$ protein) were preactivated by incubation of tissue extract aliquots with $2 \mathrm{mM}$ dithiothreitol (10 $\mathrm{min}$, room temperature), and the substrate was then added $(20 \mu \mathrm{M}, 200 \mu \mathrm{L}$ final volume). The fluorescence produced upon hydrolysis of the substrates was measured every $20 \mathrm{~s}$ in a FlexStation 3 microplate reader (Molecular Devices, USA), using $\lambda_{\text {excitation }}=380 \mathrm{~nm}$ and $\lambda_{\text {emission }}=460 \mathrm{~nm}$. The assays were also performed in the presence of the following inhibitors: $1 \mathrm{mM}$ phenylmethylsulfonyl fluoride (PMSF; inhibitor of serine proteases), $5 \mu \mathrm{M}$ E64 (irreversible inhibitor of cysteine proteases), and $1 \mu \mathrm{M} \mathrm{CA074} \mathrm{(irrever-}$ sible inhibitor of cathepsin B).

The activities of $\beta$-D-glucuronidase, $N$-acetyl- $\beta$-D-glucosaminidase, $N$-acetyl- $\beta$-D-galactosaminidase, and sulfatases were measured by spectrophotometric assays using the following substrates: 4-nitrophenyl $\beta$-D-glucuronide, 4-nitrophenyl $N$-acetyl- $\beta$-D-glucosaminide, 4-nitrophenyl $N$-acetyl- $\beta$-D-galactosaminide, and 4-nitrophenyl sulfate, respectively (Sigma-Aldrich). All assays were performed on microplates, always as triplicates, and the incubation mixtures $(150 \mu \mathrm{L}$ final volume) contained $50 \mathrm{mM}$ sodium acetate buffer, $\mathrm{pH} 5.0,2 \mathrm{mM}$ substrate, and increasing amounts of tissue extracts $(2-30 \mu \mathrm{L}$ containing 20-120 $\mu \mathrm{g}$ protein). After $1 \mathrm{~h}$ of incubation at room temperature, the 4-nitrophenol released was solubilized by addition of $1 \mathrm{M} \mathrm{NaOH}(150 \mu \mathrm{L})$, and the absorbance was measured immediately at $\lambda_{405}$ in a microplate reader (Molecular Devices).

\section{Quantification of liver protein and Western blotting}

Protein was quantified in tissue extracts by a modified Lowry procedure with bicinchoninic acid (18) (BCA Protein Assay Kit, Thermo Scientific Pierce, USA), using bovine serum albumin as standard.

The specificity of anti-cathepsin $B$ and anti- $\beta$-actin antibodies was evaluated by Western blotting (19). Tissue extracts $(1.5-2.5 \mu \mathrm{L}$ containing $30 \mu \mathrm{g}$ protein) were submitted to SDS-PAGE (12\% acrylamide with $0.32 \%$ bisacrylamide for cathepsin B; $7.5 \%$ acrylamide with $0.2 \%$ bisacrylamide for $\beta$-actin). Proteins were transferred to nitrocellulose membranes and probed with either rabbit polyclonal anti-cathepsin B or rabbit monoclonal anti- $\beta$-actin 
antibody. Specific bands were detected by secondary antibody (anti-rabbit $\operatorname{lgG}$ ) conjugated with horseradish peroxidase (HRP) and enhanced chemiluminescence (ECL) substrate. Images were obtained with the MFChemiBIS gel documentation system, where each lane represents a pool of four animals for each group.

Color images (tetramethylbenzidine; KPL, USA) and chemiluminescence images (ECL Advance Western Blotting Detection Kit; GE Healthcare, USA) were obtained with the MF-ChemiBIS gel documentation system (DNR Bio Imaging Systems Ltd., Israel) with the GelCapture 7.0.6 software for Windows ${ }^{\mathrm{TM}}$.

\section{RNA extraction and real-time reverse transcriptase- polymerase chain reaction (PCR)}

Each liver fragment $(\sim 100 \mathrm{mg})$ was disrupted in liquid nitrogen, homogenized in $1 \mathrm{~mL}$ QIAzol Lysis Reagent (QIAGEN, USA), and processed according to the manufacturer's instructions. Absorbances $\left(A_{260 / 280}\right.$ and $\left.A_{260 / 230}\right)$ were measured (ND-1000, NanoDrop, USA), and samples with ratios lower than 1.8 and 1.7 , respectively, were discarded. RNA integrity was also evaluated from $28 \mathrm{~S}$ and $18 \mathrm{~S}$ rRNA bands after agarose gel electrophoresis using Tris-borate-EDTA buffer, as previously described $(20,21)$. To avoid contamination with genomic DNA, RNA samples

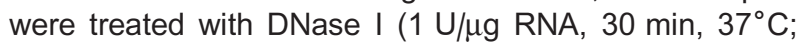
Fermentas International, Canada) followed by $25 \mathrm{mM}$ EDTA $\left(1 \mu \mathrm{L}\right.$ /enzyme unit, $\left.10 \mathrm{~min}, 65^{\circ} \mathrm{C}\right)$ to inactivate the DNase I.

One microgram of RNA was reverse-transcribed to complementary DNA (cDNA) with RevertAid M-MuLV (Fermentas International), and the resulting single-strand CDNA was amplified by quantitative PCR (qPCR) in a reaction mixture containing $0.4 \mu \mathrm{M}$ of each primer and $7.5 \mu \mathrm{L}$ SYBR Green $(15 \mu \mathrm{L}$ final volume; Rotor-Gene SYBR Green PCR Kit, QIAGEN). The thermal cycling conditions were as follows: initial $5 \mathrm{~min}$ at $95^{\circ} \mathrm{C}$, followed by $40-45$ cycles of denaturing at $95^{\circ} \mathrm{C}$ for $5 \mathrm{~s}$, annealing at $60^{\circ} \mathrm{C}$ for $10 \mathrm{~s}$, and extension at $95^{\circ} \mathrm{C}$ for $10 \mathrm{~min}$. Cycle number and cDNA concentration were adjusted so that amplified products remained within the linear range of the PCR. PCR amplification was conducted on a Corbett Rotor-Gene 6000 (QIAGEN). Each PCR was done in duplicate.

Relative gene expression was calculated by the $2^{-\Delta \Delta C_{T}}$ method developed by Livak and Schmittgen (22). In this method, it is assumed that the expression of a reference gene (housekeeping gene) is independent of external factors and that its expression is quite constant. In the present paper, two genes were used as references: ribosomal protein 29S (RPS29) and $\beta$-actin (ACTB). Other genes were tested, but they varied in the diabetic liver, compared with controls, and therefore were not used. The PCR primers (Bioneer Corp., USA) are shown in Table 1.

\section{Histology and immunohistochemistry}

For histology and immunohistochemistry, one rat in each group was anesthetized with $10 \%$ chloral hydrate (4 $\mathrm{mL} / \mathrm{kg}$ body weight) and perfused with filtered saline (150 mL, $12 \mathrm{~mL} / \mathrm{min}$ ) followed by $4 \%$ formalin in $0.1 \mathrm{M}$ phosphate buffer, pH 7.4 (500 mL, $12 \mathrm{~mL} / \mathrm{min})$. The liver was removed, cut, dehydrated, embedded in paraffin, and cut in 4- $\mu \mathrm{m}$ sections. These sections were transferred to silane-coated microscope slides and dewaxed as previously described (23).

Liver sections were stained with either hematoxylin and eosin or toluidine blue, and images were obtained with a Zeiss Axiolab microscope (Carl Zeiss Microlmaging $\mathrm{GmbH}$, Germany), equipped with an AxioCam MRc digital camera and AxioVision software.

For immunohistochemistry, the dewaxed slides were transferred to $200 \mathrm{~mL}$ prewarmed $10 \mathrm{mM}$ sodium citrate buffer, $\mathrm{pH} 6.0\left(95^{\circ} \mathrm{C}\right)$. Antigen retrieval was $30 \mathrm{~min}$ at $95^{\circ} \mathrm{C}, 20 \mathrm{~min}$ on the bench, and $5 \mathrm{~min}$ under running water. Endogenous peroxidase was blocked by $3 \%$ hydrogen peroxide (10 min, 10 times), followed by running water (10 $\mathrm{min})$ and phosphate-buffered saline (PBS; $3 \mathrm{~min}, 3$ times). Nonspecific protein binding was blocked by $200 \mu \mathrm{L} 1 \%$ bovine serum albumin (Cat. \#A3059, Sigma-Aldrich) and $2 \%$ fetal calf serum in a moist chamber at room temperature. The primary antibody was rabbit anticathepsin B (Cat. \#06-480; EMD Millipore, USA) diluted $1: 100$ in blocking solution. After an overnight incubation at $4^{\circ} \mathrm{C}$ and three 5-min washes in PBS, HRP-conjugated goat anti-rabbit IgG, secondary antibody (Cat. \#12-348, EMD Millipore) diluted 1:200 in blocking solution was added. After a 90-min incubation and three 5-min washes in PBS, nickel-enhanced diaminobenzidine (Cat. \#54-74-00, HistoMark Orange Peroxidase System; KPL) was used as HRP substrate. Then, the tissue sections were rinsed under running water and counterstained by Harris modified hematoxylin solution (Cat. \#HHS16, Sigma-Aldrich) for

Table 1. PCR primers.

\begin{tabular}{|c|c|c|}
\hline Enzyme & Forward & Reverse \\
\hline Cathepsin B & 5'-GCTATCCCTCTGGAGCATGGAAC-3' & 5'-GACGGGAGCCATTGACATGGT-3' \\
\hline Cathepsin L & 5'-AGGCAATCAGGGCTGTAATGGAG-3' & 5'-CGTTAGCCACAGCATACTCAGCTC-3' \\
\hline$\beta$-D-glucuronidase & 5'-CAGTGCTTCCACAGCGATGGA-3' & 5'-GTGATGTCAGCCTCAAAGGGGAG-3' \\
\hline$\beta$-actin & 5'-GGATGACGATATCGCTGCGCT-3' & 5'-CTGACCCATACCCACCATCACAC-3' \\
\hline Ribosomal protein S29 & 5'-GTCAGTACGCGAAGGACATAGGC-3' & 5'-CAGGGTAGACAGTTGGTTTCATTGGG-3' \\
\hline
\end{tabular}


Table 2. Body and liver weights, and glycemia of rats 10 and 30 days after streptozotocin-induced diabetes mellitus (DM) and their matched controls.

\begin{tabular}{|c|c|c|c|c|}
\hline & \multicolumn{2}{|c|}{10 Days } & \multicolumn{2}{|c|}{30 days } \\
\hline & Control $(n=13)$ & $\mathrm{DM}(\mathrm{n}=11)$ & Control $(n=13)$ & $\mathrm{DM}(\mathrm{n}=10)$ \\
\hline \multicolumn{5}{|l|}{ Body weight (g) } \\
\hline Initial & $307 \pm 15$ & $313 \pm 33$ & $300 \pm 22$ & $326 \pm 28$ \\
\hline Final & $326 \pm 19$ & $282 \pm 32^{*}$ & $325 \pm 19$ & $247 \pm 6^{*}$ \\
\hline \multicolumn{5}{|l|}{ Glycemia (mg/dL) } \\
\hline Initial & $105 \pm 9$ & $111 \pm 13$ & $108 \pm 13$ & $111 \pm 10$ \\
\hline Final & $116 \pm 28$ & $461 \pm 108^{*}$ & $108 \pm 21$ & $456 \pm 81^{*}$ \\
\hline 24-h urine volume $(\mathrm{mL})$ & $9.1 \pm 1.2$ & $97.0 \pm 8.4^{*}$ & $8.0 \pm 2.1$ & $84.6 \pm 11.9^{*}$ \\
\hline \multicolumn{5}{|l|}{ Urinary albumin (mg/24 h) } \\
\hline RID & $0.66 \pm 0.36$ & $0.89 \pm 0.19$ & $0.48 \pm 0.23$ & $2.70 \pm 1.85^{*}$ \\
\hline ELISA & $1.67 \pm 0.94$ & $2.03 \pm 0.60$ & $1.31 \pm 0.70$ & $7.78 \pm 2.95^{\star *}$ \\
\hline Liver weight (g) & $8.9 \pm 0.7$ & $10.3 \pm 1.5$ & $9.9 \pm 0.7$ & $9.3 \pm 1.3$ \\
\hline Liver/body weight $\left(\times 10^{-2}\right)$ & $2.81 \pm 0.33$ & $3.35 \pm 0.24$ & $3.33 \pm 0.20$ & $3.79 \pm 0.10^{*}$ \\
\hline
\end{tabular}

Data are reported as means \pm SD. RID: radial immunodiffusion assay. ${ }^{*} \mathrm{P}<0.05 \mathrm{DM}$ vs matched control (t-test). ${ }^{* *} \mathrm{P}<0.01$ vs matched control (t-test).

30 s. Excess hematoxylin was removed by $0.1 \% \mathrm{HCl}$ in $70 \%$ ethanol, followed by a 5 -min rinse under running water. Slides were dehydrated and mounted in Entellan (Cat. \#14800, Merck, Germany) and sealed with clear nail polish. Negative controls were incubated with blocking solution at each step.

\section{Statistical analysis}

Statistical analysis was performed with the PASW Statistics software (SPSS Statistics) for Windows ${ }^{\mathrm{TM}}$ (version 18.0.0). The Shapiro-Wilk test was used to evaluate data for normality, and data were standardized (z-score) when the parametric distribution was not observed. Bootstrap (a resampling method) was also used to check for the stability of the experimental data. Results are reported as means $\pm S D$, except for enzyme kinetics, when means $\pm 95 \%$ confidence interval are reported. Differences between groups were analyzed by ANOVA. Values of $\mathrm{P}<0.05$ were considered to be significant, except where otherwise stated.

\section{Results}

\section{Glycemia, albuminuria, and liver weight}

The body weight of the animals at the beginning (day zero) and at the end (either $10^{\text {th }}$ or $30^{\text {th }}$ day) of the experiment, glycemia, urine volume, albuminuria, and liver weight are reported in Table 2. Two animals of the DM day 10 group did not become diabetic (glycemia $<250 \mathrm{mg} / \mathrm{dL}$ ) and were excluded, and three animals of the DM day 30 group died before the end of the experimental period. In contrast to normal controls, which gained weight during the experimental period, all the diabetic rats showed a progressive and significant loss of body weight. In the controls, glycemia was maintained in the normal range during the entire experimental period, but in the diabetic rats glycemia, as well as urine volume, were very high on days 10 and 30. Significant albuminuria (evaluated by two different methods) appeared only on day 30 . Liver weight did not vary in the diabetic rats, compared with the controls, but liver/body weight increased on day 30 .

\section{Activity of liver proteases}

The kinetics of formation of fluorescent product (MCA) from two different substrates [Z-FR-MCA and $\varepsilon-\mathrm{NH}_{2}-$ caproyl-Cys(Bzl)-Cys(Bzl)-MCA] is shown in Figure 1. The kinetics was measured in the presence and absence of the inhibitors PMSF, E64, and CA074, which inhibit serine proteases, cysteine proteases, and cathepsin B, respectively. PMSF had no effect on enzymatic activities of the substrates used here. In contrast, enzyme activities were very low in the presence of E64, indicating that cysteine proteases were the main enzymes acting on the substrates. Z-FR-MCA was the substrate for cathepsin B and also for other cysteine proteases, while $\varepsilon-\mathrm{NH}_{2}$-caproyl-Cys(Bzl)Cys(Bzl)-MCA was the substrate mainly for cathepsin B (inhibited by CA074).

Cathepsin B corresponds to about one-half of total cysteine proteases in rat liver, both normal and diabetic (Figure 2), and all cysteine protease activities were decreased in the diabetic liver compared with normal activity, on both the $10^{\text {th }}$ and $30^{\text {th }}$ days.

\section{Activities of glycosidases and sulfatase}

In contrast to the proteases, only the specific activity of $\beta$-D-glucuronidase was decreased, and only on the $10^{\text {th }}$ day of STZ-DM (Figure 3). The specific activities of $N$-acetyl- $\beta$ D-glucosaminidase and $N$-acetyl- $\beta$-D-galactosaminidase 


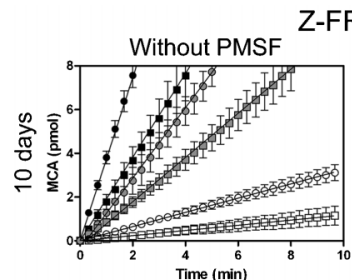

Z-FR-MCA
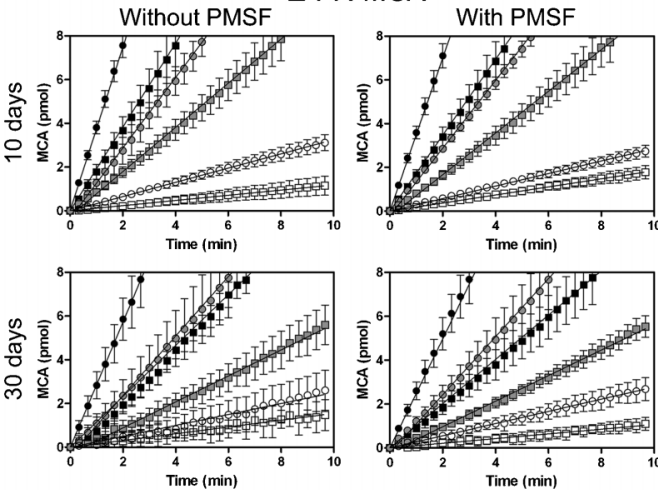

$\rightarrow \mathrm{NL}$

$\rightarrow \mathrm{NL}+\mathrm{CAOT4}$

$\rightarrow \mathrm{DM}+\mathrm{CAOT4}$

$\rightarrow \mathrm{NL}+\mathrm{E} 64$

$\mathrm{DM}+\mathrm{E} 64$

$\varepsilon-\mathrm{NH}_{2}$-caproyl-Cys

Without PMSF
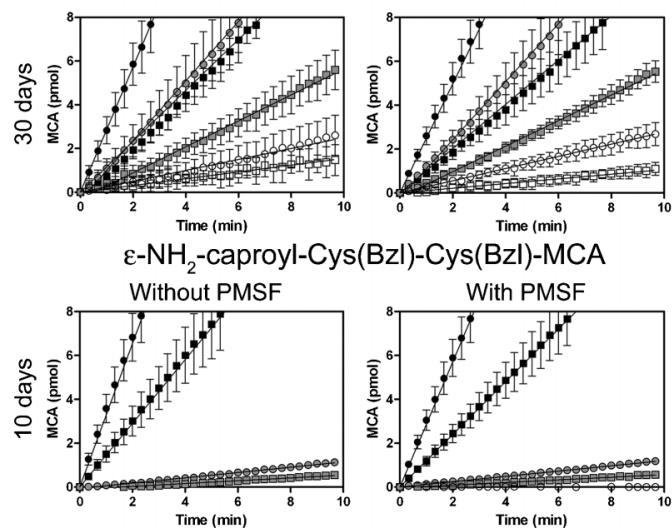$$
\sqrt{2}+2
$$
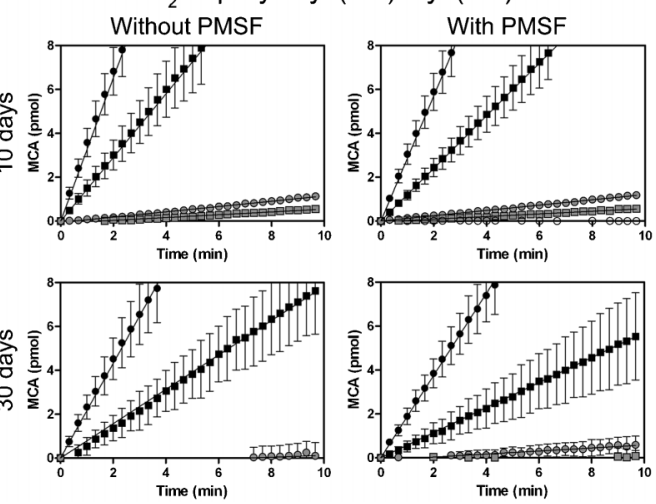

Figure 1. Kinetics of cysteine protease activities in diabetic (DM) and normal $(\mathrm{NL})$ rat livers. Tissue extracts $(2-6 \mu \mathrm{L}$ containing $50 \mu \mathrm{g}$ protein) were preactivated by incubation of tissue extract aliquots with $2 \mathrm{mM}$ dithiothreitol (10 $\mathrm{min}$, room temperature). The following substrates were then added $(20 \mu \mathrm{M}, 200 \mu \mathrm{L}$ final volume): Z-FR-MCA (substrate for cysteine proteases), or $\varepsilon^{-}$ $\mathrm{NH}_{2}$-caproyl-Cys(Bzl)-Cys(Bzl)-MCA (substrate for cathepsin $\mathrm{B}$ ). The fluorescence produced upon hydrolysis of the substrates was measured every $20 \mathrm{~s}$ in FlexStation 3 (Molecular Devices, USA), using $\lambda_{\text {exc }}=380 \mathrm{~nm}$ and $\lambda_{\text {emi }}=460 \mathrm{~nm}$. The assays were also performed in the presence of inhibitors: $1 \mathrm{mM}$ phenylmethylsulfonyl fluoride (PMSF, inhibitor of serine-proteases), $5 \mu \mathrm{M}$ E64 (irreversible inhibitor of cysteine-proteases), and $1 \mu \mathrm{M} \mathrm{CA074}$ (irreversible inhibitor of cathepsin B). A maximum of $10 \%$ substrate consumption was considered, and each point represents the mean $\pm 95 \%$ confidence interval of four replicates for all animals in each group.

did not vary in the diabetic liver, compared with normal activity. Decreased specific activity of sulfatases was observed only on the $30^{\text {th }}$ day of DM.

Liver expression (mRNA) of cathepsin B, cathepsin L, and $\beta$-D-glucuronidase (qPCR)

The expression of three lysosomal enzymes (cathep$\sin B$, cathepsin L, and $\beta$-D-glucuronidase) was analyzed by qPCR in normal and diabetic rat liver. The results are reported as $2^{-\Delta \Delta C}$ T relative to the two housekeeping genes, RPS29 and ACTB (Figure 4).
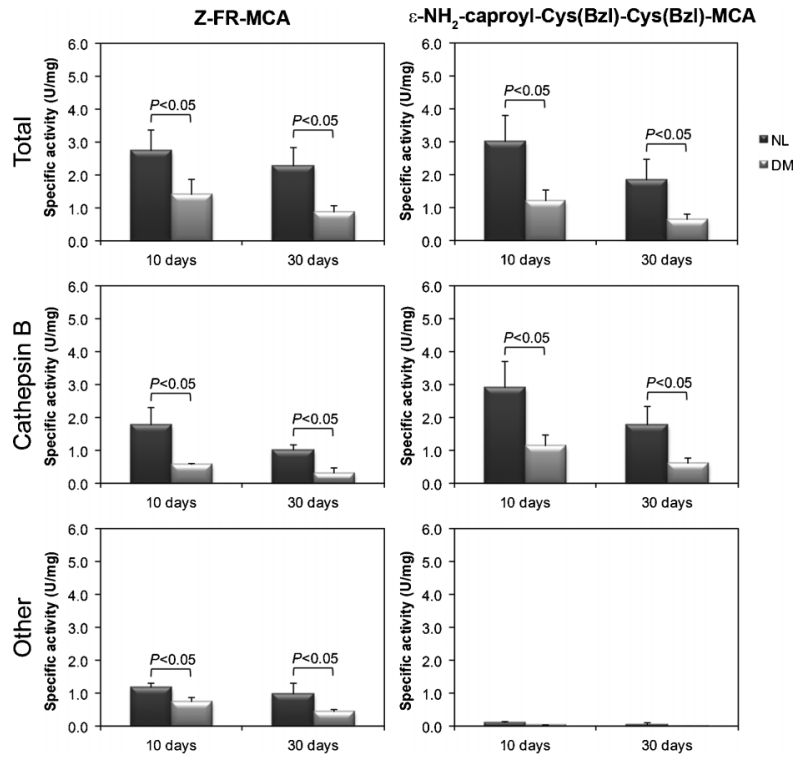

Figure 2. Specific activities of cysteine proteases in diabetic (DM) and normal (NL) rat livers. The assays were performed as described in Figure 1, except that specific activities are shown (enzyme units/mg protein, $\mathrm{U} / \mathrm{mg}$ ). The following substrates were used: Z-FR-MCA (substrate for cysteine proteases), or $\varepsilon-\mathrm{NH}_{2-}$ caproyl-Cys(Bzl)-Cys(Bzl)-MCA (substrate for cathepsin B). One enzyme unit was defined as the amount of enzyme that produces $1 \mathrm{nmol}$ product/min. Data are reported as means \pm SD. Statistically significant differences between $\mathrm{NL}$ and $\mathrm{DM}$ are reported as $\mathrm{P}<0.05$ (ANOVA).
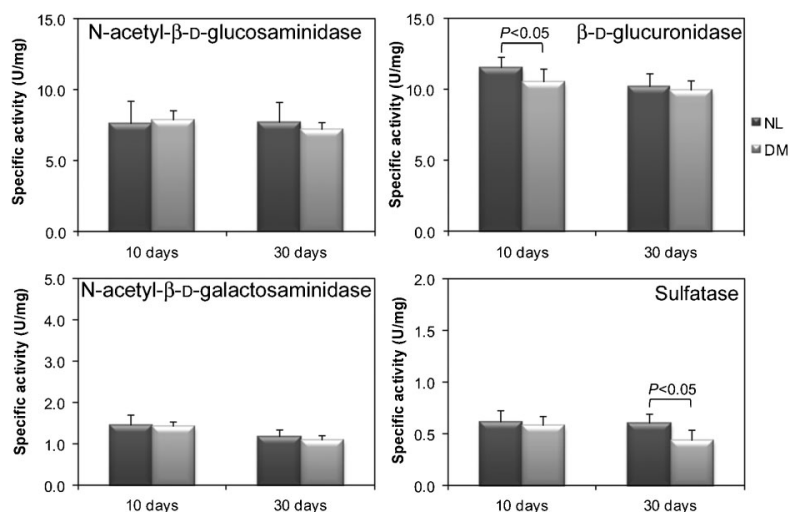

Figure 3. Specific activities of glycosidases and sulfatases in diabetic (DM) and normal (NL) rat livers. Tissue extracts (1-14 $\mu \mathrm{L}$ containing 20-120 $\mu \mathrm{g}$ protein) were incubated with p-nitrophenyl monosaccharides or p-nitrophenyl sulfate. One enzyme unit $(U)$ was defined as the amount of enzyme that produces $1 \mathrm{nmol}$ product $/ \mathrm{min}$. Data are reported as means \pm SD. Statistically significant differences between $\mathrm{NL}$ and $\mathrm{DM}$ are reported as $\mathrm{P}<0.05$ (ANOVA). 

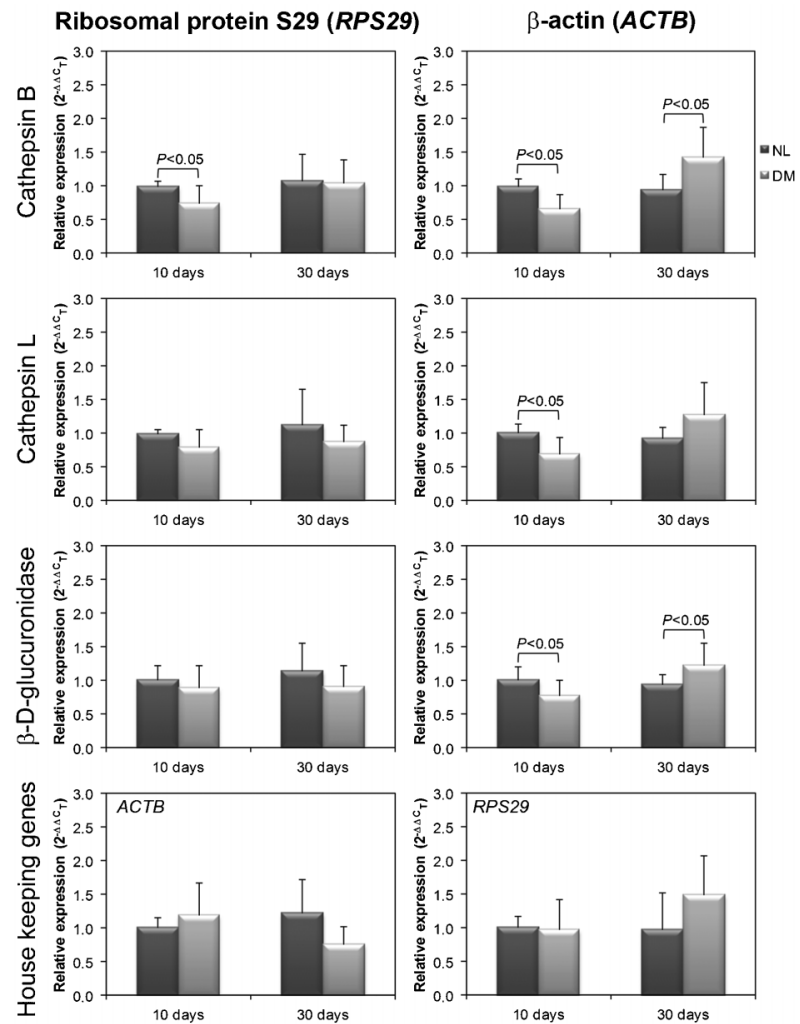

Figure 4. Expression (mRNA) of cathepsin $B$, cathepsin $L$, and $\beta$-D-glucuronidase in diabetic (DM) and normal (NL) rat livers. The expression of mRNA was normalized either by ribosomal protein S29 (RPS29) or $\beta$-actin (ACTB). Data are reported as means \pm SD. Statistically significant differences between $\mathrm{NL}$ and $\mathrm{DM}$ are reported as $\mathrm{P}<0.05$ (ANOVA).

The relative expression of the two housekeeping genes used here did not vary on the $10^{\text {th }}$ day of DM compared with controls, indicating that both can be used as reference. Nevertheless, on the $30^{\text {th }}$ day, the expression of ACTB decreased (relative to RPS29) or RPS29 increased (relative to $A C T B$ ) in DM (Figure 4), indicating that at least one of them is not a good reference gene.

On the $10^{\text {th }}$ day of $D M$, relative to ACTB, expression of the three enzymes decreased, whereas, relative to RPS29, only the expression of cathepsin B decreased. In contrast, on the $30^{\text {th }}$ day, relative to $A C T B$, the expression of cathepsin $B$ and $\beta$-D-glucuronidase increased, whereas, relative to RPS29, they did not vary. It is possible that the observed increase in expression of cathepsin $B$ and $\beta$-D-glucuronidase relative to $A C T B$ is only apparent, since ACTB decreased relative to RPS29. Furthermore, this apparent increase does not correlate to the specific activities of the enzymes (see Figures 2 and 3), suggesting that, in the diabetic liver, RPS29 is a better housekeeping gene than ACTB.
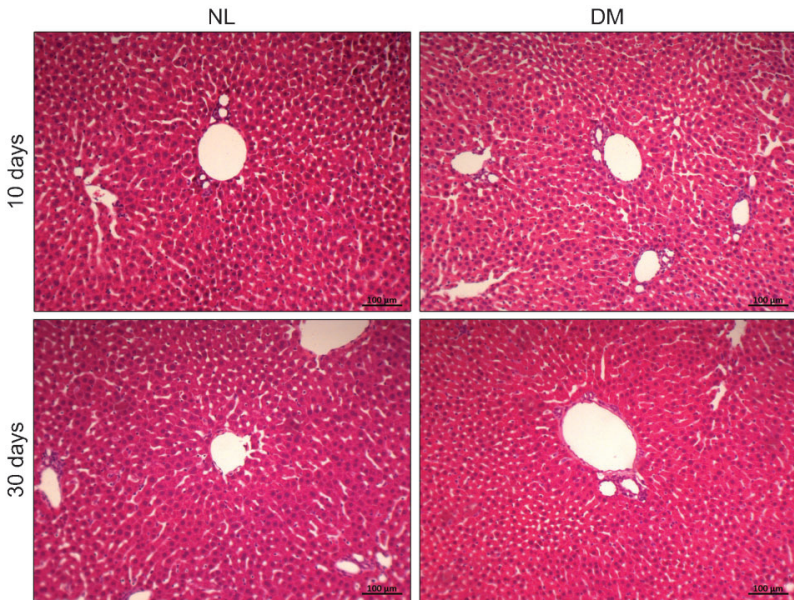

Figure 5. Optical microscopy of diabetic (DM) and normal (NL) rat livers. Tissue samples from normal and diabetic livers (10 and 30 days of diabetes) were included in paraffin, cut into $4-\mu \mathrm{m}$ sections, and stained with hematoxylin and eosin. No significant changes in liver morphology were observed. Magnification bar: $100 \mu \mathrm{m}$.

\section{Histology, immunohistochemistry, and Western blotting}

No changes were observed in the general histological organization of the tissue (Figure 5). Figure 6 shows that, upon toluidine blue staining, metachromatic cells appeared both in normal and diabetic liver (perivascular), and cytoplasmatic granules appeared in all hepatocytes, both normal and diabetic. Tiny granules were also stained by immunohistochemistry for cathepsin B (Figure 7). The specificity of the antibodies was analyzed by Western blotting, which revealed the expected bands of procathepsin B ( $\sim 40 \mathrm{kDa})$ and native cathepsin B (26 and $30 \mathrm{kDa})$.

\section{Discussion}

Although much of the pioneering research on autophagy comes from studies in liver, and lysosomes were first described in liver (9), there are few studies on the expression and activities of lysosomal enzymes that act upon protein and sulfated polysaccharides in the diabetic liver. In 1974, Amherdt et al. (24) reported an increase in hepatic lysosome volume in severe diabetes induced by $100 \mathrm{mg} / \mathrm{kg} \mathrm{STZ}$, primarily due to autophagosomes. In 1978, Dice et al. (25) showed that the degradation of proteins is accelerated in the liver of insulin-deficient rats, and, in 1988, Jordá et al. (26) reported a decrease in the half-life of liver mitochondrial ATPase in the severe diabetic state, possibly associated with hepatic autophagy. These data indicate that the liver autophagy pathway seems to be implicated in diabetic complications. Nevertheless, the activities and expression of lysosomal enzymes were not measured. 


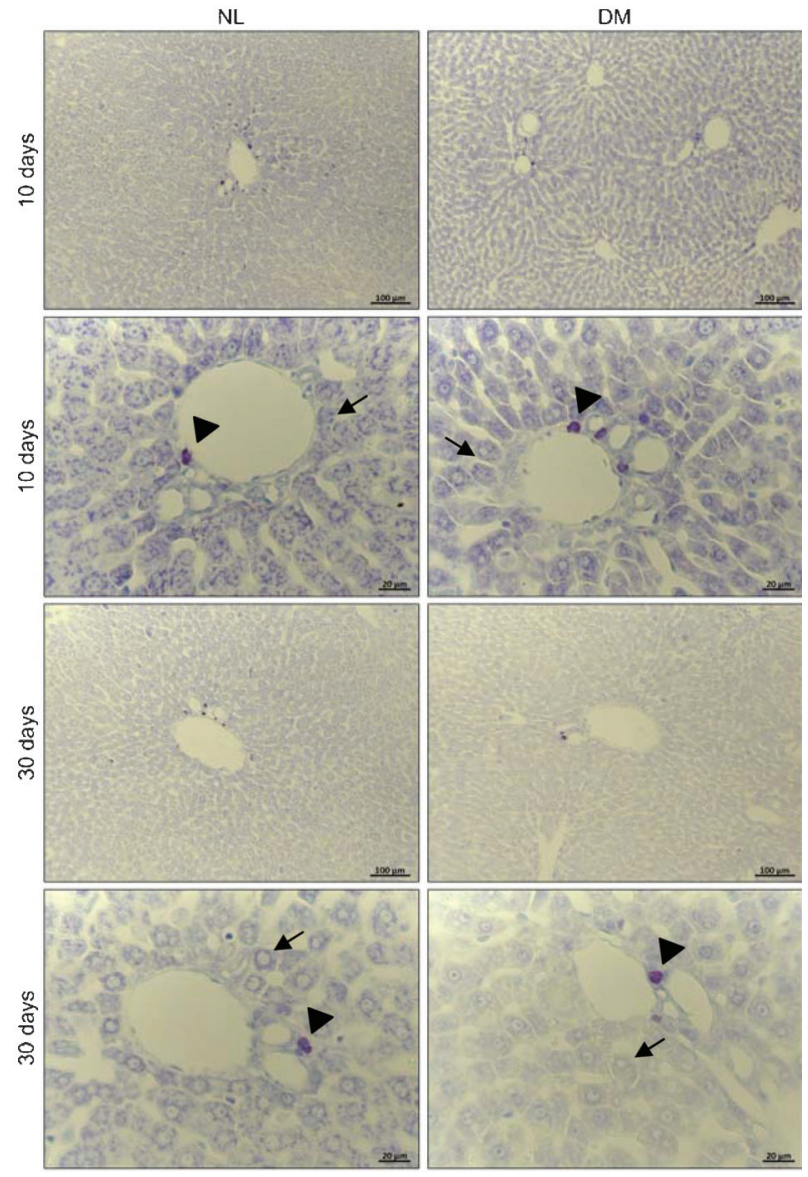

Figure 6. Optical microscopy of diabetic (DM) and normal (NL) rat livers. The experiment was performed as described in Figure 5 , except that the liver sections were stained by toluidine blue. Note the metachromatic cells around vessels (arrowheads), and the cytoplasmatic granules (arrows) in hepatocytes.

In this article, we report a significant decrease in the specific activities of cysteine proteases, especially cathep$\sin B$, in the liver of rats with STZ-DM, on the $10^{\text {th }}$ and $30^{\text {th }}$ days of the disease. The decrease in liver cysteine protease activities was much greater than that of kidney (liver: 50$60 \%$ decrease; kidney: $11-15 \%$ decrease, see Ref. 5 for comparison), although in liver the specific activities of these enzymes were much lower (liver: 2.3-2.7 U/mg, Figure 2; kidney: $12.5-14.1 \mathrm{U} / \mathrm{mg}$ ) (5). Decreases in the expressions (mRNA) of cathepsin B and cathepsin L were also observed on the $10^{\text {th }}$ day after DM induction, suggesting that the lower gene expression may be one of the mechanisms responsible for the lower enzyme activities.

Conversely, the picture concerning sulfated polysaccharides was very different. The specific activities of most glycosidases were higher in liver than in kidney (5) as follows: $\beta$-D-glucuronidase, liver: 10.2-11.5, kidney: 2.6-3.1 U/mg; $N$ acetyl- $\beta$-D-glucosaminidase, liver: 7.7, kidney: 3.5-3.9 U/mg; $N$-acetyl- $\beta$-D-galactosaminidase, liver: 1.1-1.5, kidney:
(A)

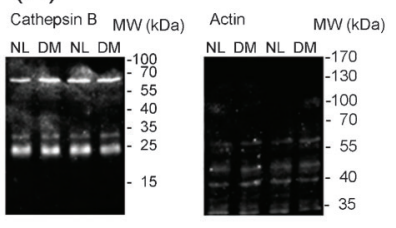

(B)

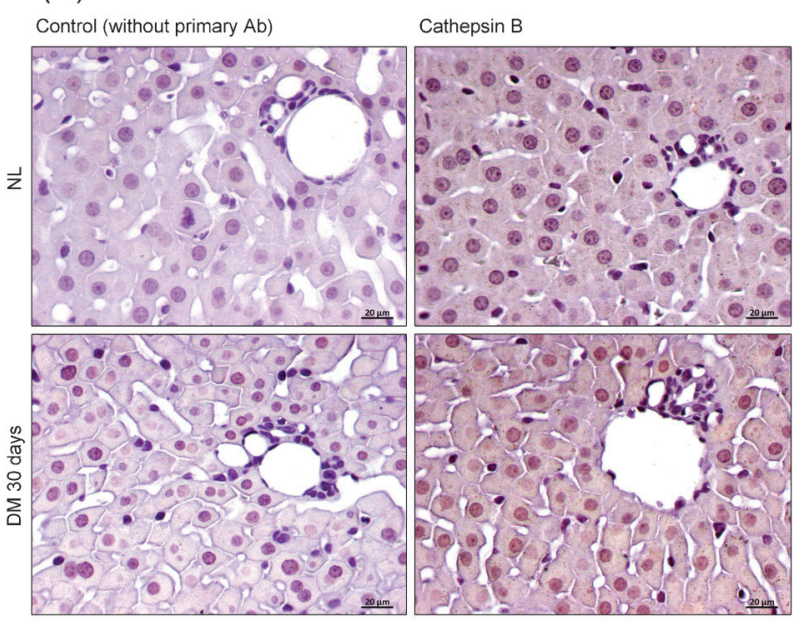

Figure 7. Western blotting and immunohistochemistry of cathepsin $B$ in diabetic (DM) and normal (NL) rat livers. $A$, Tissue extracts $(1.5-2.5 \mu \mathrm{L}$ containing $30 \mu \mathrm{g}$ protein) were submitted to SDS-PAGE $(12 \%$ acrylamide with $0.32 \%$ bisacrylamide for cathepsin B; $7.5 \%$ acrylamide with $0.2 \%$ bisacrylamide for $\beta$ actin). Proteins were transferred to nitrocellulose membranes for Western blotting, and probed with either rabbit polyclonal anticathepsin B or rabbit monoclonal anti- $\beta$-actin antibody. Specific bands were detected by secondary antibody (anti-rabbit lgG) conjugated with horseradish peroxidase (HRP) and ECL substrate. Images were obtained with the MF-ChemiBIS gel documentation system. Each lane represents a pool of 4 animals of each group. $B$, Tissue sections were incubated with primary rabbit polyclonal anti-cathepsin $\mathrm{B}$ antibody. Controls were incubated with blocking solution, without any primary antibody. Anti-rabbit IgG conjugated with HRP was used as secondary antibody, and nickel enhanced diaminobenzidine was used as HRP substrate. Tissues were counterstained with hematoxylin. Cathepsin B-containing structures are brownish, while hematoxylin-stained nuclei are purple. Magnification bars: $20 \mu \mathrm{m}$.

2.2-2.5 U/mg. Nevertheless, in contrast to kidney, most activities did not vary in STZ-DM relative to control. A transitory and slight decrease in the expression and activity of $\beta$-D-glucuronidase ( $8 \%$ ) was observed only on the $10^{\text {th }}$ day of diabetes, while the activities of $N$-acetyl- $\beta$-D-glucosaminidase and $N$-acetyl- $\beta$-D-galactosaminidase did not vary.

It is noteworthy that the specific activity of liver sulfatase was found to have decreased $30 \%$ on the $30^{\text {th }}$ day after DM induction. This decrease could be responsible for the previously reported accumulation of dextran sulfate in the diabetic liver (2), since the action of sulfatases precedes the action of glycosidases in the digestive pathway of sulfated polysaccharides (27). 
There were no apparent changes in liver morphology, suggesting that the observed effects on lysosomal proteases and sulfatases were not a consequence of STZ toxicity. Immunohistochemistry for cathepsin B showed cytoplasmatic granules in hepatocytes, corroborating the lysosomal location for these enzymes. The specificity of the antibodies was confirmed by Western blotting, which revealed the presence of the expected bands. Toluidine blue staining also showed cytoplasmatic granules in hepatocytes, both in normal and diabetic liver.

Taken together, our results suggest that STZ-DM leads to decreased cathepsin and sulfatase activities in liver. It seems that this decrease is not a consequence of general lysosome failure, since the activities of glycosidases did not concurrently decrease in the diabetic liver. Also, it is not a consequence of general STZ liver toxicity, since no histological changes were visible.

Degradation of sulfated polysaccharides is usually initiated by endoglycosidases (matrix or lysosomal), which produce sulfated poly- and oligosaccharides as products, and these are the substrates for sulfatases. Only desulfated products are susceptible to the action of

\section{References}

1. Cadaval RA, Kohlman O, Michelacci YM. Urinary excretion of glycosaminoglycans and albumin in experimental diabetes mellitus. Glycobiology 2000; 10: 185-192, doi: 10.1093/glycob/ 10.2.185.

2. de Lima CR, Aguiar JA, Michelacci YM. Reduced urinary excretion of sulfated polysaccharides in diabetic rats. Biochim Biophys Acta 2005; 1741: 30-41, doi: 10.1016/j.bbadis.2004. 10.001.

3. Michelacci YM, Cadaval RA, Rovigatti RM, Kohlman O. Renal and urinary glycosaminoglycans in an experimental model of chronic renal failure in rats. Exp Nephrol 2001; 9: 40-48, doi: 10.1159/000020706.

4. Hadad SJ, Michelacci YM, Schor N. Proteoglycans and glycosaminoglycans synthesized in vitro by mesangial cells from normal and diabetic rats. Biochim Biophys Acta 1996; 1290: 18-28, doi: 10.1016/0304-4165(95)00183-2.

5. Peres GB, Juliano MA, Simoes MJ, Michelacci YM. Lysosomal enzymes are decreased in the kidney of diabetic rats. Biochim Biophys Acta 2013; 1832: 85-95, doi: 10.1016/ j.bbadis.2012.09.011.

6. Tanaka Y, Kume S, Kitada M, Kanasaki K, Uzu T, Maegawa $\mathrm{H}$, et al. Autophagy as a therapeutic target in diabetic nephropathy. Exp Diabetes Res 2012; 2012: 628978, doi: $10.1155 / 2012 / 628978$.

7. de Duve C, Wattiaux R. Functions of lysosomes. Annu Rev Physiol 1966; 28: 435-492, doi: 10.1146/annurev.ph.28. 030166.002251.

8. Yin $X M$, Ding $W X$, Gao $W$. Autophagy in the liver. Hepatology 2008; 47: 1773-1785, doi: 10.1002/hep.22146.

9. de Duve C, Pressman BC, Gianetto R, Wattiaux R, Appelmans F. Tissue fractionation studies. 6. Intracellular distribution patterns of enzymes in rat-liver tissue. Biochem J 1955; 60: 604-617. exoglycosidases that remove specific sugars, one by one, from the nonreducing end of the molecule. If one of these lysosomal enzymes is reduced (or absent), partially degraded molecules accumulate in lysosomes, and may impair cell function. Stuffed lysosomes may appear as cytoplasmatic granules in histological analysis, especially with toluidine blue staining.

The decrease in sulfatase activity observed in the present study explains the previously reported (2) dextran sulfate build-up in the diabetic liver.

\section{Acknowledgments}

The authors want to express their gratitude to Prof. Dr. Ivarne L.S. Tersariol for helpful discussion on kinetics and specificity of cathepsin B, to Prof. Dr. Miriam Galvonas Jasiulionis for her supportive assistance in the qPCR experiments, and to Prof. Dr. Manuel de Jesus Simões for help with the histology preparation and analysis. Research supported by FAPESP (\#2009/11817-2, \#2010/16022-5, \#2013/07109-8), CNPq (\#08642/20104), and CAPES.
10. de Duve C. My love affair with insulin. J Biol Chem 2004; 279: 21679-21688, doi: $10.1074 / j b c . X 400002200$.

11. Singh R, Kaushik S, Wang Y, Xiang Y, Novak I, Komatsu M, et al. Autophagy regulates lipid metabolism. Nature 2009; 458: 1131-1135, doi: 10.1038/nature07976.

12. Papackova Z, Palenickova E, Dankova H, Zdychova J, Skop V, Kazdova L, et al. Kupffer cells ameliorate hepatic insulin resistance induced by high-fat diet rich in monounsaturated fatty acids: the evidence for the involvement of alternatively activated macrophages. Nutr Metab 2012; 9: 22, doi: 10.1186/1743-7075-9-22.

13. Kalamidas SA, Kondomerkos DJ. Autophagosomal glycogen-degrading activity and its relationship to the general autophagic activity in newborn rat hepatocytes: The effects of parenteral glucose administration. Microsc Res Tech 2010; 73: 495-502, doi: 10.1002/jemt.20788.

14. Reckelhoff JF, Tygart VL, Mitias MM, Walcott JL. STZinduced diabetes results in decreased activity of glomerular cathepsin and metalloprotease in rats. Diabetes 1993; 42: 1425-1432, doi: 10.2337/diab.42.10.1425.

15. Watanabe N, Kamei S, Ohkubo A, Yamanaka M, Ohsawa $\mathrm{S}$, Makino $\mathrm{K}$, et al. Urinary protein as measured with a pyrogallol red-molybdate complex, manually and in a Hitachi 726 automated analyzer. Clin Chem 1986; 32: 1551-1554.

16. Laplante A, Liu D, Demeule M, Annabi B, Murphy GF, Daloze $P$, et al. Modulation of matrix gelatinases and metalloproteinase-activating process in acute kidney rejection. Transp/ Int 2003; 16: 262-269, doi: 10.1111/j.14322277.2003.tb00297.x.

17. Alves LC, Almeida PC, Franzoni L, Juliano L, Juliano MA. Synthesis of $\mathrm{N}$ alpha-protected aminoacyl 7-amino-4methyl-coumarin amide by phosphorous oxychloride and preparation of specific fluorogenic substrates for papain. 
Pept Res 1996; 9: 92-96

18. Smith PK, Krohn RI, Hermanson GT, Mallia AK, Gartner FH, Provenzano MD, et al. Measurement of protein using bicinchoninic acid. Anal Biochem 1985; 150: 76-85, doi: 10.1016/0003-2697(85)90442-7.

19. de Lima CR, de Arimatea dos Santos Junior J, Nazario AC Michelacci YM. Changes in glycosaminoglycans and proteoglycans of normal breast and fibroadenoma during the menstrual cycle. Biochim Biophys Acta 2012; 1820: 10091019, doi: 10.1016/j.bbagen.2012.04.010.

20. Sambrook J, Russel DW. Molecular cloning: a laboratory manual. Cold Spring Harbor: CSH Laboratory Press; 2001.

21. Fleige S, Pfaffl MW. RNA integrity and the effect on the realtime qRT-PCR performance. Mol Aspects Med 2006; 27 : 126-139, doi: 10.1016/j.mam.2005.12.003.

22. Livak KJ, Schmittgen TD. Analysis of relative gene expression data using real-time quantitative PCR and the 2(-Delta Delta C(T)) Method. Methods 2001; 25: 402-408, doi: $10.1006 /$ meth.2001.1262.

23. Robertson D, Savage K, Reis-Filho JS, Isacke CM. Multiple immunofluorescence labelling of formalin-fixed paraffinembedded (FFPE) tissue. BMC Cell Biol 2008; 9: 13, doi 10.1186/1471-2121-9-13.

24. Amherdt M, Harris V, Renold AE, Orci L, Unger RH. Hepatic autography in uncontrolled experimental diabetes and its relationships to insulin and glucagon. J Clin Invest 1974; 54 188-193, doi: 10.1172/JCl107742.

25. Dice JF, Walker CD, Byrne B, Cardiel A. General characteristics of protein degradation in diabetes and starvation. Proc Natl Acad Sci U S A 1978; 75: 2093-2097, doi: 10.1073/ pnas.75.5.2093

26. Jordá A, Perez-Pastor E, Portoles M. Effect of streptozotocin-diabetes on rat liver mitochondrial adenosine triphosphatase turnover. Biochem J 1988; 251: 621-624.

27. Freeze $\mathrm{HH}$. Genetic disorders of glycan degradation. Chapter 41. In: Varki A, Cummings RD, Esko JD, Freeze HH, Stanley $\mathrm{P}$, Bertozzi CR, et al. (Editors), Essentials of glycobiology. 2nd edn. New York: Cold Spring Harbor Laboratory Press; 2009. Available from: http://www.ncbi.nlm.nih.gov/books/NBK1908/. Accessed June 27, 2013. 